NUKHBATUL 'ULUM : Jurnal Bidang Kajian Islam

Vol. 4, No. 1 (2018) : Hal. 84-96

Website: https://journal.stiba.ac.id

ISSN : 2685-7537 (online) 2338-5251 (Printed)

\title{
LANDASAN SYARIAH DALAM ETIKA PERIKLANAN
}

\section{Hasnan Hanif}

Komunitas Kajian Ekonomi Islam Indonesia

Email : iif_alfatih@yahoo.com.

\section{Keywords :}

Sharia, Ethics, advertisement.

\section{ABSTRACT}

\begin{abstract}
The conventional ethics concept has difference color with Islamic ethics on implementation in daily lives. The ethics in Islamic teaching follows the rule of valid and invalid (halal and haram) including the way of reaching, using, advertising and marketing of the product. The conventional etbics concept leads good and bad values in buman perspective. Ethics was defined as an action that done based on the good moral principles where Akblaq was being the main reference in doing of Islamic economics production. The foundation of Islamic ethics in advertisement is to follow the Sharia guideline that has been determined. The value of Islamic advertisement as follows: Shiddiq, (honest), Fathonah. (Clever). Amanah. (trusted) Tabligh. (delivered). Istiqomah. (consistent).
\end{abstract}




\section{PENDAHULUAN}

Persaingan di dalam pasar global adalah sesuatu yang tak dapat dihindari. Baik itu mulai dari pelaku ekonomi rumah tangga maupun dalam skala besar seperti perusahaan. Para pelaku bisnis melakukan pemasaran produknya ditengah-tengah persaingan yang sangat tajam. Bahkan tak segansegan beberapa perusahaan melanggar aturan-aturan baik itu peraturan normatif maupun non- normatif.

Perusahaan pun melakukan pemasaran dengan berbagai cara, baik melalui media massa maupun elektronik, membuat iklan semenarik mungkin untuk menarik pelanggan dan konsumen, mengadakan promosi besar-besaran ataupun dalam bentuk kerjasama lainnya yang akhirnya mengarah kepada keuntungan bagi perusahaaan itu sendiri.

Salah satu instrumen yang sangat memikat konsumen dalam pemasaran adalah iklan. Iklan adalah sebuah komunikasi yang persuasif yang mampu merubah perilaku khalayak. Sebuah iklan diciptakan untuk menggiring pola pikir atau tindakantindakan sesuai dengan si pembuat iklan.

Pada saat ini banyak sekali bukubuku marketing yang berisi strategi beriklan, kiat-kiat yang harus dicapai, cara-cara mempengaruhi konsumen tetapi kebanyakan buku tersebut bisa jadi tidak menjelaskan konsep etika dalam beriklan terlebih lagi kalau itu ditinjau dari perspektif Islam.

\footnotetext{
${ }^{1}$ Beritaunik.net. Sule $X L$ VS Sule $A S$. http://www.beritaunik.net (diakses pada tanggal 24 November 2017).

${ }^{2}$ Aditya Panji. Operator Seluler Dilarang.Umbar .Janji Palsu di Iklan (Ed: Reza
}

Beberapa kasus perang produk iklan sering kali kita temui di televisi salah satu contoh adalah perang produk iklan provider seluler antara XL dan Telkomsel pada waktu lalu. Berkali-kali dapat kita lihat bagaimana kartu XL menurunkan tarifnya hingga batas minimum Rp 0.1,- / detik tidak kalah kartu AS pun memurahkan tarifnya. Persaingan ini pun berlanjut manakala aktor Sule yang semula mengiklankan kartu XL berpindah ke kartu AS. Dengan saling menyindir satu sama lain ${ }^{1}$.

Tidak hanya itu masih banyak perusahaan jasa telekomunikasi seperti provider seluler yang melakukan pelanggaran-pelanggaran praktik usaha kurang sehat dalam memperluas pangsa pasar operator seluler. Mereka menawarkan tarif yang tidak wajar, SMS maupun internet gratis, memberi kartu perdana gratis, serta undian berhadiah. Persaingan melalui iklan saat ini cenderung dapat merugikan masyarakat karena informasi yang disampaikan belum sepenuhnya memenuhi kriteria obyektif, lengkap, dan belum bisa dipertanggungjawabkan. Malah terkadang mengorbankan kualitas layanan ${ }^{2}$.

Jika di teliti dibeberapa situs sumber produk mereka seperti, produk sabun mandi, rokok, penjualan mobil dan lainnya selalu menampilkan gambar perempuan yang auratnya terbuka. ${ }^{3}$ ini semua adalah etika yang tidak dilandaskan dengan landasan Syariah. Meskipun secara konsep etika tersebut tidak merugikan konsumen

Wahyudi) http://tekno.kompas.com. (Diakses tanggal 24 November 2017).

${ }^{3}$ Agung Kurniawan. Adu Seksi Para Model Sepeda Motor?. Kompas.com. (dikases tanggal. 24 November 2017). Dan halaman www.lux.com 
namun mendatangkan keburukan (mafsadat) dalam pandangan Islam.

Saat ini iklan banyak yang tidak sesuai dengan syariah. Bahkan iklan dengan kenyataannya jauh sekali perbedaaannya. Berbagai macam iklan memberikan penipuan kepada masyarakat. Beberapa iklan juga menggunakan perempuan untuk menarik konsumen. Mengeksploitasi tubuh perempuan dalam menawarkan berbagai penjualan produk seperti, kosmetik, mobil, motor, minuman, parfum dan sebagainya meskipun tidak ada keterkaitan antara perempuan dengan yang diiklankan mereka masih saja mengiklankan untuk menarik konsumen. Bahkan yang lebih parah lagi biasanya dalam pameran-pameran banyak sekali dijumpai perempuan yang memakai pakaian minim ditampilkan untuk menjaga stand pameran produk mereka dan menugaskan perempuan tersebut merayu konsumen untuk membeli terhadap produk mereka. Model promosi ini melanggar akblaqul karimah.

Permasalahan yang terjadi diatas sesungguhnya adalah karena pelaku ekonomi khususnya dalam hal ini perusahaan yang menjual produk telah mengabaikan nilai-nilai etika. Pengaibaian nilai etika tersebut berdampak pada persaingan yang tidak sehat, saling menjatuhkan, mengejek menghalalkan segala cara bahkan mencari kesalahan dipihak lain.

Sesungguhnya perbuatan diatas tidak dibenarkan didalam Islam. Islam mengajarkan bagaimana melakukan kegiatan periklanan didasarkan pada prinsip-prinsip islam, yaitu tidak boleh curang, tidak boleh menipu maupun

${ }^{4}$ Abdul Mannan. Teori dan Praktek Ekonomi Islam (Jogjakarta: Dana Bakti Wakaf, 1997), h. 288. bersumpah. Seperti hadits yang diriwayatkan oleh bukhari. Abu Hurairah berkata "Aku mendengar Rasulullah SAW berkata "dengan menggunakan sumpah palsu barang barang jadi terjual, tapi menghilangkan berkahnya, yang terkandung didalamnya. (HR. Bukhari). ${ }^{4}$ Sebab itulah diperlukan etika islami dalam melakukan periklanan produk bagi perusahaan.

Etika merupakan refleksi manusia tentang apa yang dilakukan dan dikerjakannya. Etika adalah wahana orientasi bagi usaha manusia untuk menjawab suatu pertanyaan yang amat fundamental, bagaimana manusia harus hidup, bagaimana bertindak, dan lain-lain. Etika menuntun orang agar sungguhsungguh menjadi orang baik, agar memiliki sikap etis, dengan mengutamakan kejujuran dan kebenaran.

Kenyataan telah menunjukkan bahwa tidak ada satu pun manusia mampu melaksanakan tata kehidupannya secara sempurna dan memuaskan dalam kesendiriannya. Manusia tidak bisa terlepas dan terbebas dari tatanan nilai. Namun, dalam tata pergaulan antara manusia satu dengan lainnya hampir dapat dipastikan bahwa kehendak bebas yang sebebas-bebasnya tidak pernah dapat terwujud.

Islam mempunyai konsep tersendiri mengenai etika karena sumber etika Islam berasal dari Syariat dan sesuai dengan firman Allah SWT. Islam mengajarkan untuk saling tolong - menolong dalam berbuat kebaikan 
sebagaimana dalam firman Allah

SWT Q.S. Al-Maidah/3:2

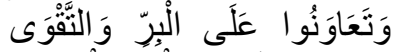

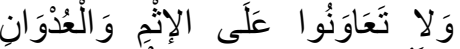

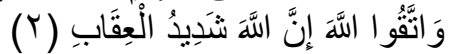

Terjemahannya:

Dan tolong-menolonglah kamu dalam (mengerjakan) kebajikan dan takwa, dan jangan tolongmenolong dalam berbuat dosa dan pelanggaran. dan bertakwalah kamu kepada Allah, Sesunggubnya Allah Amat berat siksa-Nya.

Tentu saja dampak dari pengabaian etika adalah sangat merugikan pihak konsumen. Apalagi ditengah persaingan yang sangat kompetitif ini kadang advertiser perusahaan menggunakan segala cara untuk mendapatkan keuntungan. Maka disinilah pentingnya sebuah etika periklanan yang berlandasakan syariah. sehingga pelaku usaha tidak terjebak pada profit oriented semata dalam mengiklankan barang dan jasa. Ia harus mengutamakan manfaat, kebaikan serta keberkahan sehingga berbuah pada kemaslahatan.

Perbedaan konsep etika konvensional dan etika islam tentu memberikan warna yang berbeda dalam implementasi kehidupan. etika didalam islam dikendalikan oleh aturan halal dan haram, baik cara memperoleh, memanfaatkan, mengiklankan, memasarkan produk dan menjualnya. ini sama sekali berbeda dengan konsep etika konvensional. Dimana etika bukanlah faktor yang dominan untuk dibicarakan. Karena etika konvensional tersebut berlandaskan konsep sekularisme yang mengarah kepada

${ }^{5}$ Veithzal. Dkk. Islamic Business And Economic Ethics (Jakarta: Bumi Aksara, 2012), h. 92. materialisme. Veithzal (2012) mengatakan dari azas sekularisme inilah, seluruh bangunan karakter bisnis non-islam tidak memperhatikan aturan halal dan haram dalam setiap perencanaan, pelaksanaan dan segala usaha yang dilakukan dalam meraih tujuan-tujuan bisnis ${ }^{5}$.

Jadi, sistem etika periklanan konvensional hanya diarahkan kepada duniawi saja dan menafikkan nilai-nilai ruhiyah karna perbedaan antara konsep etika konvensional dan etika islam sangat tajam sekali. Maka diperlukannya etika islami dalam aktivitas advertisement agar terjadi persaingan yang sehat menuju kemaslahatan umat.

Sebagai kekuatan moral, tentunya Islam berusaha memperbaiki kualitas hidup manusia menjadi lebih baik sehingga menjadi tugas setiap muslim menghubungkan perilaku marketer dengan etika yang berlandasakan Al-Qur'an dan Sunnah. Dalam kajian ekonomi Islam peran sentral etika tidak dipisahkan karena Islam juga tidak memisahkan ilmu dengan akhlak, politik, dengan etika dan sebagainya. Dengan permasalahan ketidakjelasan batasan etika konvensional maka perlu dirumuskan bagaimana landasan syariah mengenai etika periklanan yang nantinya dapat kita lihat titik terang perbedaan yang signifikan diantara keduanya.

\section{PEMBAHASAN}

\section{Definisi Etika}

Etika berasal dari bahasa yunani ethos dengan makna watak atau adat kebiasaan. Bersamaan dengan kata "moral" etika berkembang menjadi 
kajian filsafat atau ilmu pengetahuan tentang moralitas dalam the american heritage conscise dictionary disebutkan bahwa etika memiliki 3 pengertian, yaitu:

a. Prinsip tentang tingkah laku yang benar dan baik atau kumpulan dari prinsip-prinsip tersebut. (a principle of right or good conduct or a body of such principles).

b. Suatu sistem dari prinsip dan nilai moral. (a system of moral principles or values).

c. Ethic dengan menambahkan "s" yang berarti jamak merupakan kajian terhadap moralitas secara umum dan pilihan - pilihan moral yang spesifik. (ethics used with a singuler verb means a study of the general nature and of specific moral choices). ${ }^{6}$

Dalam kamus webster new colligiate dictionary. Disebutkan etika merupakan karakter istimewa, sentimen, tabiat moral, atau keyakinan yang membimbing individu, kelompok atau institusi. ${ }^{7}$

Mengacu pada beberapa pengertian diatas ada 4 hal yang berkaitan dengan etika.

Dilihat dari objek pembahasannya, etika membahas perbuatan atau tindakan manusia.

a. Dilihat dari sumber ajaranya, etika berasal dari pemikiran manusia yaitu filsafat dan ilmu pengetahuan.

${ }^{6}$ The American Heritage, Concise Dictionary of the English Language. Dalam https://ahdictionary.com diakses pada tanggal 13 Maret 2018.

${ }^{7}$ Merriam Webster, Webster?]s New Collegiate Dictionary (G. And c. Merriam Company: USA, 1847), h. 393

${ }^{8}$ Abbudin Nata dalam Fahrudin Sukarno. Etika Produksi Dalam Perspektif b. Dilihat dari fungsinya, etika merupakan instrumen pemberi nilai atau menetapkan perbuatan manusia apakah termasuk perbuatan baik, buruk, benar, mulia, hina, berguna dan sebagainya.

c. Dilihat dari sifatnya, etika berlaku relatif, sehingga dapat berubah sesuai waktu dan konteks zamannya. ${ }^{8}$

Fahrudin Sukarno menjelaskan tentang pengertian etika yang mengacu pada konteks diatas, Ia menyebutkan etika merupakan kajian terhadap sistem nilai yang muncul dari perbuatan manusia. Sistem nilai ini menjadi standar untuk menilai apa yang mendasari manusia melakukan hal tersebut ? mengapa tidak melakukan hal yang sebaliknya?.'

Sedangkan Buchari Alma (2003) dalam bukunya yang berjudul "DasarDasar Etika Bisnis Islam" menyebutkan Istilah etika sebagai suatu perbuatan standar (standard of conduct) yang memimpin individu dalam membuat keputusan. Etik ialah suatu study mengenai perbuatan yang salah dan benar dan pilihan moral yang dilakukan oleh seseorang. ${ }^{10}$

Sejalan dengan definisi diatas Hussain Sahata menyebutkan :

The term ethics in this code is used to mean a set of principles and norms to which business people should adhere in their business dealings, conduct and relations in order to reach the shores of

Ekonomi Islam. (Bogor: Al-Azhar Press. 2011), h. 144.

${ }^{9}$ Fahrudin Sukarno. Etika Produksi Dalam Perspektif Ekonomi Islam. (Bogor: AlAzhar Press. 2011). : h. 144

${ }^{10}$ Buchari Alma. Dasar-Dasar Etika Bisnis Islami (Bandung: Alfabeta Bandung. 2003), h. 52. 
saftey. it is also a criterion for reward orpunishment ${ }^{11}$

(istilah Etika dalam kode ini biasanya maknanya adalah seperangkat prinsip dan normanorma yang mana pebisnis harus mematuhi dalam urusan bisnis mereka, perilaku dan hubungan untuk mencapai tepi keselamatan. Ini juga merupakan kriteria untuk mendapatkan hadiah atau hukuman).

Jadi berdasarkan definisi mengenai etika diatas jelaslah bahwa etika adalah sebuah tindakan yang dilakukan berdasarkan pada prinsipprinsip moral yang baik. Dimana akhlak menjadi acuan utama dalam manusia melakukan kagiatan produksi dalam ekonomi Islam.

Rafik Issa Bekum menyebutkan istilah etika yang paling dekat berhubungan dalam al-Quran adalah Khuluq. Al-Quran juga menggunakan sejumlah istilah lain yang menggambarkan konsep tentang kebaikan (khair), birr (kebenaran), qist (persamaan), 'adl (kesetaraan dan keadilan), haqq (kebenaran dan kebaikan), ma'ruf (mengetahui dan menyetujui) dan takwa (ketakwaan). Tindakan yang terpuji disebut sebagai sayyi'at ${ }^{12}$.

\section{a. Definisi Iklan}

Iklan adalah Segala bentuk pesan tentang suatu produk disampaikan

\footnotetext{
${ }^{11}$ Hussain Hussain Shahata. Business

Ethics In Islam. (Cairo: Al-Falah Fondation.1999) h. 09.

${ }^{12}$ Rafik Issa Bekum dalam Veithzal. Dkk, Islamic Business And Economic Ethics. (Jakarta: Bumi Aksara. 2012). h. 3.

13Persatuan Perusahaan Periklanan Indonesia. http://www.p3i-pusat.com (diakses tanggal 24 November 2017).

${ }^{14}$ Sugiarto Durianto Widjaja dan Supraktino, Invasi Pasar Dengan Iklan Yang Efektif (Jakarta: Gramedia Pustaka Utama,2003), h. 1
}

melalui suatu media, dibiayai oleh pemrakarsa yang dikenal, serta ditujukan kepada sebagian atau seluruh masyarakat. ${ }^{13}$

Iklan merupakan suatu proses komunikasi yang bertujuan untuk membujuk dan menggiring orang untuk mengambil tindakan yang menguntungkan bagi pihak pembuat iklan." 14

Iklan bisa didefinisikan sebagai bentuk komunikasi nonpersonal yang menjual pesan-pesan persuasif dari sponsor yang jelas untuk mempengaruhi orang membeli produk dengan membayar sejumlah biaya untuk media. ${ }^{15}$

Menurut Guinn, Allen, dan Semenik dalam buku yang berjudul Advertising \& Integrated Brand Promotion mengemukakan bahwa periklanan merupakan sebuah proses komunikasi. Ketiga tokoh tersebut menyatakan bahwa "Communication is a fundamental aspect of human existence, and advertising is a communication. ${ }^{16 " 1}$ (komunikasi adalab aspek fundamental dari keberadaan manusia dan mengiklankan adalab sebuab komunikasi.)

Kasmir dalam Nur Rianto (2010) mengatakan juga bahwa iklan adalah sarana promosi yang digunakan oleh perusahaan. Informasi yang diberikan adalah nama produk, manfaat produk, harga produk, serta keuntungankeuntungan produk dibandingkan

${ }^{15}$ Rachmat Kriyantono, Teknik Praktis Riset Komunikasi: Disertai Contoh Praktis Riset Media. Public Relations, Advertising, Komunikasi Organisasi, Komunikasi Pemasaran (Jakarta: Kencana Prenada Media Group. 2008), h. 174.

${ }^{16}$ O?guinn, thomas, chris T. Allen, Richard J Semenik. 2006. Advertising And Integrated Brand Promotion USA : Thomson South-Western p. 13. 
produk yang ditawarkan oleh pesaing. Tujuan promosi lewat iklan adalah berusaha untuk menarik consumer. ${ }^{17}$

Jadi dari definisi diatas dapat disimpulkan bahwa iklan adalah sebuah produk apapun yang disampaikan melalui media dengan cara membujuk (persuasif) agar konsumer membeli produk tersebut dengan harga berapapun.

\section{b. Tujuan Periklanan.}

Setiap kegiatan pasti mempunyai tujuan yang dicapai. Begitu pula dengan periklanan adalah untuk meningkatkan omzet penjualan, dengan jalan mempengaruhi konsumen secara tidak langsung. Dengan periklanan ini diharapkan dapat meningkatkan penjualan. menurut Swasta dan Irawan (1986:369) menyatakan bahwa tujuan pokok dari periklanan adalah untuk meningkatkan permintaan bagi produk. Permintaan dapat ditingkatkan dengan cara:

- Menaikkan jumlah pembeli.

- Dan atau menaikkan tingkat penggunaan barang diantara pembeli yang ada.

Iklan seharusnya legal, layak, jujur dan benar. Dilakukan secara setara, tepat dan efisien. Terlihat sepakat secara jujur dan menghargai pelanggan. Seiring dengan prinsip yang bisa diterima atas kompetisi yang jujur.

\section{Pembahasan}

Kode etik periklanan tentu sangat diharapkan untuk membatasi pengaruh iklan. Etika periklanan harus berlandaskan nilai-nilai syariah. Dari landasan Syari'ah mengenai ajaran etika periklanan maka Islam mengajarkan ajaran etika beriklan sebagai berikut :

a. Jangan mudah mengobral sumpah, jadi dalam

${ }^{17}$ M. Nur Rianto Al-Arif, Dasar-Dasar Pemasaran Bank Syariah. Bandung. Penerbit: Alfabeta Bandung. 2010. HIm. 174. beriklan janganlah mengucapkan janji yang sekiranya janji itu tidak dapat dipenuhi.

b. Jujur, terbuka dan tidak menyembunyikan cacat barang dagangan. Rasulullah SAW bersabda. "seseorang muslim itu adalah saudara muslim lainnya, maka tidak halal bagi seorang muslim membeli dari saudaranya suatu pembelian yang ada cacatnya kecuali telah dijelaskan terlebih dahulu". (HR.Ahmad disahihkan oleh Al-Abani).

c. Menjaga agar selalu memenuhi akad dan janji serta kesepakatankesepakatan diantara dua belah pihak (pembeli dan penjual).

d. Menghindari mengiklankan kepalsuan yang bertujuan menarik perhatian pembeli dan mendorongnya untuk membeli, karena rasullulah melarang najasy. (Muttafaq'alaih).

e. Rela dengan laba sedikit karena itu akan mengundang kepada kecintaan manusia dan menarik banyak pelanggan serta mendapat berkah dalam rezeki.

f. Jangan mudah mengobral sumpah, jadi dalam beriklan janganlah mengucapkan janji yang sekiranya janji tersebut tidak bisa ditepati. 
Rasulullah SAW bersabda ; "hindarilah banyak bersumpah dalam melakukan jual beli, karena sumpah itu menghabiskan barang kemudian membatalkan (barokahnya) (HR. Muslim).

g. Menjaga agar selalu memenuhi akad dan janji serta kesepakatankesepakatan diantara dua belah - pihak (pembeli dan penjual). Allah SWT berfirman dalam Q.S. AlMaidah/3:1.

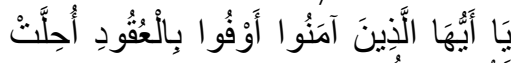

Terjemahannya:

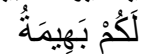

"Hai orang-orang yang beriman, penubilah aqad-aqad itu"

Pada dasarnya iklan adalah alat untuk menginformasikan, menawarkan dan menjual produk atau jasa. Didalam Islam dilarang keras melakukan penipuan, kebohongan, janji palsu, iklan porno, serta publikasi produk yang menghalalkan segala cara. (Ismail Yusanto:2002:172). Dusta sangat ditentang oleh Islam sebagaimana disebutkan dalam Q.S. Al-Hāj/22:30

Terjemahannya:

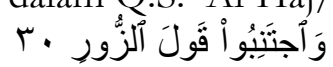
dusta"

"dan jaubilah perkataan-perkataan

Bencana terbesar di dalam pasar saat ini adalah meluasnya tindakan dusta dan bathil dalam berdagang atau berbisnis, misalnya berbohong dalam mempromosikan dalam produknya atau menetapkan harga, terlebih diiringi bersumpah atas nama Allah.

Dalam sebuah hadits dikatakan "empat tipe manusia yang dimurkai allah : penjual yang suka bersumpah, orang miskin yang congkak, orang tua renta yang berzina, dan iman yang zalim' (HR. Nasa'i dan ibn Hibban).

Nilai -Nilai Syariah dalam Etika Beriklan.

Ada beberapa nilai-nilai syariah yang mengambil konsep dari keteladanan sifat Rasulullah SAW. Nilai-nilai syariah ini adalah merupakan panduan dalam beriklan sehingga nantinya dapat tercipta iklan syariah. Nilai-nilai itu antara lain adalah bersumber dari sifat-sifat Rasulullah sebagai berikut :

1. Shiddiq: artinya memiliki kejujuran dan selalu melandasi ucapan, keyakinan, serta perbuatan berdasarkan ajaran Islam. Tidak ada satu ucapan pun yang saling betentangan dengan perbuatan. Allah SWT senantiasa memerintahkan kepada setiap orang beriman untuk memiliki sifat shiddiq dan menciptakan lingkungan yang shiddiq. Didalam AlQur'an, Shiddiq disebutkan sebanyak 154 kali.

Beberapa diantaranya dalam QS. Al-Imran : 15-17.

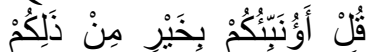

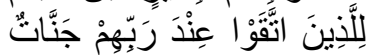

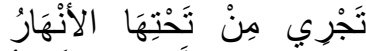

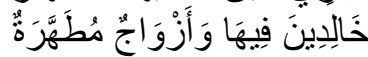

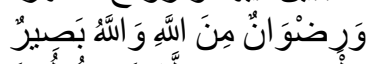

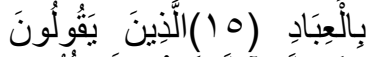

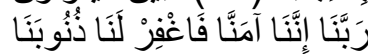

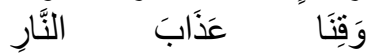

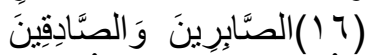

وَالَْقَانْتِينَ

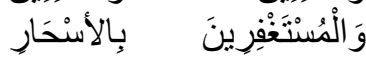

(IV)

\section{Terjemahannya:}

Katakanlah: "Inginkah aku kabarkan kepadamu apa yang lebih baik dari yang demikian itu?". 
Website: https://journal.stiba.ac.id

ISSN : 2685-7537 (online) 2338-5251 (Printed)

untuk orang-orang yang bertakwa (kepada Allah), pada sisi Tuban mereka ada surga yang mengalir dibawahnya sungai-sungai; mereka kekal didalamnya. dan (mereka dikaruniai) isteri-isteri yang disucikan serta keridhaan Allah. dan Allah Maha melibat akan hamba-bamba-Nya.

(yaitu) orang-orang yang berdoa: Ya Tuban Kami, Sesunggubnya Kami telah beriman, Maka ampunilab segala dosa Kami dan peliharalah Kami dari siksa neraka,". (yaitu) orang-orang yang sabar, yang benar, yang tetap taat, yang menafkabkan hartanya (di jalan Allab), dan yang memohon ampun di waktu sahur ${ }^{18}$

Ini menandakan pentingnya sikap shiddiq dalam kehidupan sehari-hari. Selain itu, shiddiq merupakan sifat kenabian. Nabi Muhammad SAW menegaskan, "wajib bagi kalian berlaku jujur, sebab jujur membawa kepada kebaikan, dan kebaikan menunjukkan jalan ke surga. Seseorang yang senantiasa jujur dan memperbatikan kejujuran, ia akan termaktub di sisi Allab atas kejujurannya. Sebaliknya, janganlah berdusta karena dusta mengarah kepada kejahatan, dan kejahatan membawa ke neraka. Seseorang yang berdusta yang memperbatikan kedustaannya, ia

18 Sahur: waktu

sebelum fajar menyingsing mendekati subuh. tercatat di sisi allah sebagai pendusta. (HR. Bukbari-Muslim dari Ibnu Mas'ud).

Hal penting dari nasihat Nabi diatas adalah bahwa jujur merupakan sarana mutlak untuk mencapai kebaikan tatanan masyarakat. Oleh karenanya, shiddiq bukan sekedar wacana pribadi (untuk individu), tapi juga wacana publik, yaitu perlunya sebuah sistem yang jujur juga.

Dalam nilai shiddiq ini tercermin ketika sebuah perusahaan jujur dalam mengiklankan produknya, memberikan pemahaman kepada consumer bahwa produk yang diiklankannya ini akan mendatangkan kemaslahatan bukan kemudharatan. Ia akan menunjukkan apa yang tidak baik dari produk ini sehingga apa yang diiklankan oleh perusahaan dapat dipertanggungjawabkan di dunia dan akhirat.

2. Fathonah.

Artinya, mengerti, memahami dan menghayati secara mendalam segala sesuatu yang terjadi dalam tugas dan kewajiban fathonah berkaitan dengan kecerdasan. Yang bukan hanya kecerdasan rasio semata tapi pada menekankan pada kecerdasan emosional dan spritual. Seseorang yang mempunyai kepekaan emosional dan spritual akan mengiklankan sesuatu yang 
memberikan ketenangan bathin kepada consumen. Ia akan mengiklankan sesuatu yang mendatangkan kebaikan, bernilai pendidikan yang baik bagi jiwa concumer. Iklan yang mendidik, mencerdaskan masyarakat merupakan nilai yang dapat diambil dari nilai fathonah ini.

Amanah.

Memiliki makna tanggung jawab dalam melaksanakan setiap tugas dan kewajiban. Amanah ditampilkan dalam keterbukaan, kejujuran, pelayanan prima dan ihsan dalam segala hal. Sifat amanah harus dimiliki oleh setiap mukmin apalagi untuk seseorang yang memiliki pekerjaan sebagai advertiser (pengiklanan) dalam sebuah perusahaan. Seorang mukmin ketika mendapatkan amanah akan berupaya melaksanakan dengan sebaik-baiknya. Dalam QS al-Nisa 58 disebutkan sebagai berikut :

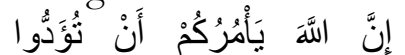

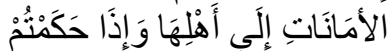

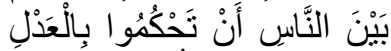

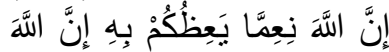

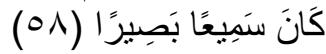

Terjemahannya:

menerimanya, dan
(menyurub kamu) apabila
menetapkan bukum di
antara manusia supaya
kamu menetapkan dengan
adil. Sesunggubnya Allab
memberi pengajaran yang
sebaik-baiknya kepadamu.
Sesunggubnya Allah
adalab Maha mendengar
lagi Maha melibat.

menerimanya, dan

(menyurub kamu) apabila

menetapkan bukum di

kamu menetapkan dengan

adil. Sesunggubnya Allah.

memberi pengajaran yang

sebaik-baiknya kepadamu.

Sesunggubnya Alla

lagi Maha melibat.
3. Tabligh.

Kata tabligh, dalam kamus besar bahasa Indonesia artinya penyampaian. Sedangkan menurut Syaikh Muhammad Nawawi (t.t.: 43), tabligh adalah menyampaikan perintah Allah. Sifat-sifat Nabi Muhammad SAW, disebutkan oleh Muhammad Husain Haekal (1965) sebagai berikut: sifatnya yang sangat rendah hati, bila ada yang mengajaknya bicara ia mendengarkan hati-hati sekali tanpa menoleh kepada orang lain. Tidak saja mendengarkan kepada yang mengajaknya bicara, bahkan ia memutarkan seluruh badannya. Bicara sedikit sekali, lebih banyak ia mendengarkan. Bila bicara selalu sungguh-sungguh, tetapi sungguhpun demikian ia tak melupakan ikut membuat humor dan bersendau gurau, namun apa yang dikatakannya selalu yang sebenarnya. Bila ia marah tidak pernah sampai tampak kemarahannya. Semua itu terbawa oleh kodratnya yang selalu lapang dada, berkemauan baik dan menghargai orang lain. Bijaksana, murah hati dan murah bergaul. Mempunyai tujuan pasti, berkemauan keras, tegas dan tak pernah ragu dalam tujuannya (Haikal, 2006: 69). Sebagaimana Allah berfirman Q.S. alAhzab/33:70-71).

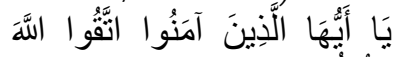

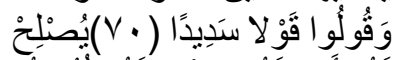

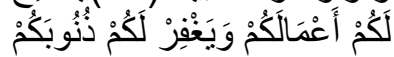

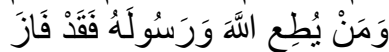

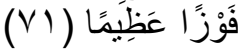


Terjemahannya:

Hai orang-orang yang

beriman, bertakwalah

kamu kepada Allah dan

katakanlah perkataan

yang benar (qaulan

sadidan), niscaya Allah

memperbaiki bagimu

amal-amalmu dan

mengampuni bagimu

dosa-dosamu. Dan

barang siapa menaati

Allah dan Rasul-Nya,

maka sesungguhnya ia

telah mendapatkan

kemenangan yang besar".

Dalam hal etika periklanan dalam Islam, Ibn al-Ukhuwwah

(1983),

menyatakan bahwa adalah tidak etis bagi penjual atau petugas pemasaran memuji kualitas produk beserta atributnya secara berlebihan, namun dalam realita mereka tidak memilikinya. Saed (2001) menyatakan bahwa, menurut prinsip-prinsip Islam, teknik promosi penjualan seharusnya tidak menggunakan daya tarik seksual, emosional, penakutan, iklan palsu, dan hasil penelitian palsu, semua mempunyai unsur-unsur dari paksaan, yang digolongkan sebagai perilaku tidak etis. Lebih jauh lagi, etika Islam melarang keras stereotip perempuan dalam iklan, dan menggunakan fantasi berlebihan. Penggunaan bahasa dan perilaku sugestif, serta penggunaan perempuan sebagai obyek untuk memikat dan menarik pelanggan juga tidak diperbolehkan. ${ }^{19}$

Tabligh dalam konteks penelitian ini diimplementasikan melalui kemampuan tenaga beriklan dalam hal penyampaian kualitas produk beserta atributnya secara bijak sesuai realita, untuk menghindari kesan pemberian harapan yang berlebihan tentang kualitas produk yang ditawarkan kepada pelanggan. Artinya

menyampaikan, mengajak sekaligus memberikan contoh kepada pilak lain untuk melaksanakan ketentuan ketentuan ajaran Islam dalam setiap gerak aktivitas memasarkan produk melalui instrumen periklanan. Tabligh yang disampaikan pada hikmah, sabar, argumentatif dan persuasif akan menumbuhkan hubungan kemanusiaan yang semakin solid dan kuat.

Sifat kepemimpinan Nabi SAW bila dikaitkan dengan konsep periklanan tentunya adalah sebuah risalah untuk menyampaikan pesanpesan dakwah dan keilahian yang mengharapkan dapat mengajak consumer kepada jalan yang baik. Interaksi perusahaan dengan consumer pun terjalin baik melalui iklan yang syar'i. Perusahaan juga memposisikan sebagai pendakwah yang akan mengembangkan marketing syariah kedepan nantinya.

${ }^{19}$ (Saeed, 2001, vol. 32: 127-142). 
4. Istiqomah.

Artinya konsisten. Hal ini memberikan makna bahwa sebuah perusahaan dalam mengiklankan produknya selalu istiqomah dalam menerapkan aturan syariah. Sebuah perusahaan harus dapat dipegang janjinya, tidak diperkenankan sebuah perusahaan mengiklankan produk hanya melihat moment-moment tertentu. Misalkan saja iklan syar'i yang hanya ada pada bulan ramadhan. Ketika bulan ramadhan telah lewat maka ia kembali lagi mengiklankan tanpa dibingkai nilai-nilai syari'i.

Larangan Mengiklankan BarangBarang Haram.

Nilai dan moral yang pertama ditekankan dalam Islam adalah larangan menjual barang-barang haram. Apalagi mencoba untuk mengiklankannya. Termasuk kategori barang-barang yang dilarang beredar adalah (khamr) adalah barang yang menyebabkan seseorang dapat mabuk (hilang akal sehat) ketika meminumnya dan mengancam kesehatan. Mengiklankan barang ini berarti mencoba merusak generasi bangsa. Termasuk mengiklankan produkproduk dengan strategi pornografi maupun porno aksi dan apa saja yang dapat mengikis akidah dan etika umat manusia. Ikut mengedarkan dan mempromosikan barang-barang tersebut berarti ikut juga bekerjasama dalam perbuatan dosa atau bahkan melakukan pelanggaran terhadap apa yang telah dilarang oleh Allah SWT.

\section{PENUTUP}

$\begin{array}{cc}\text { Islam mengajarkan agar } \\ \text { aktivitas } & \text { perusahaan dalam }\end{array}$ mempromosikan produknya melalui instrumen iklan haruslah berlandasakan nilai - nilai syariah. Adapun nilai - nilai tersebut adalah seperti, Amina (amuna, Sbidq, Labw alhadits, ifk, idz̧bar al-haq, adil dan tidak memihak.

Dari landasan Syari'ah tersebut maka ajaran etika periklanan dalam bisnis Islam mengikuti panduan yang telah ditetapkan syariat. Landasan syariah tersebut mengajarkan agar jangan perusahaan itu mengobral sumpah, sehingga dalam beriklan tidak ada penipuan. Seperti yang disabdakan Rasulullah SAW "seseorang muslim itu adalah saudara muslim lainnya, maka tidak balal bagi seorang muslim membeli dari saudaranya suatu pembelian yang ada cacatnya kecuali telah dijelaskan terlebih dahulu". (HR. Abmad disabibkan oleh AlAbani).

didalam Islam beriklan haruslah dalam lingkaran syariah sehingga jelas mana batas yang halal dan haram. Islam melarang mengiklankan cara, memperoleh, menjual yang mendatangkan kemaslahatan. Karna itu akan merugikan manusia khususnya para consumer.

Nilai-Nilai dalam Etika Beriklan merupakan kunci panduan perusahaan dalam beriklan. Nilai-nilai periklanan syariah tersebut adalah seperti berikut ini. Sbiddiq, Fathonah. Amanah. Tabligh. Istiqomah. Nilai ini ketika dimplementasikan akan menghasilkan etika iklan yang di ridhoi Allah SWT.

\section{DAFTAR PUSTAKA}


Alma, Buchari. 2003. Dasar-dasar Etika Bisnis Islami, Bandung: Alfabeta, cet. Ke-3.

Amri, Mafri. 1999. Etika Komunikasi Massa dalam Pandangan Islam. Jakarta. Penerbit PT Logo Wacana Ilmu. Cetakan ke 1.

Husain Syahatah dan Siddiq Muh AlAmin Adh-Dhahir. 2005. (Penj: Saptono) Transaksi dan Etika Bisnis Islam. Jakarta.

Hussain, Hussain Shahata. Business Ethics In Islam. Egypt Cairo. Penerbit. Al-Falah Fondation.

Jusmailani, dkk. 2008. Bisnis Berbasih Syariah. Jakarta. Penerbit : Bumi Aksara.

Kamus Besar Bahasa Indonesia (KBBI) offline 1.4

Karim, Adiwarman A. 2007. Ekonomi Mikero Islami. Edisi ke 3. Jakarta. Penerbt: PT Raja Grafindo.

Kasmir. 2004. Pemasaran Bank. Jakarta. Penerbit: Kencana.. Hlm: 177.

Lihat Kamus Webster's New Collegiate Dictionary. G. And C. Merriam Company. USA. 393

M. Nur Rianto Al-Arif. 2010. DasarDasar Pemasaran Bank Syariah. Bandung. Penerbit: Alfabeta Bandung.

Mannan, Abdul. 1997. Teori dan Praktek Ekonomi Islam. Jogjakarta. Penerbit: Dana Bakti Wakaf.

O'guinn, thomas, chris T. Allen, Richard J Semenik. 2006. Advertising And Integrated Brand Promotion USA : Thomson SouthWestern

Kriyantono, Rachmat. 2008. Teknik Praktis Riset Komunikasi: Disertai Contoh Praktis Riset Media. Public Relations, Advertising, Komunikasi Organisasi, Komunikasi Pemasaran. Jakarta: Kencana Prenada Media Group.
Sugiarto Durianto Widjaja dan Supraktino. 2003. Invasi Pasar Dengan Iklan Yang Efektif. Gramedia Pustaka Utama. Jakarta.

Sukarno, Fahrudin. 2011. Etika Produksi Dalam Perspektif Ekonomi Islam. Bogor. Penerbit: Al-Azhar Press.

The American Heritage Concise Dictionary. 3rd Edition Houghton Miffin Company. 1994.

Veithzal. dkk. 2012. Islamic Business And Economic Ethics. Jakarta. Penerbit: Bumi Aksara.

Yusanto dan Widjajakusuma 2002. Menggagas Bisnis Islami, Cetakan I, Jakarta: Gema Insani Press.

\section{Sumber Website}

Beritaunik.net. Sule XL VS Sule AS. http://www.beritaunik.net diakses pada tanggal 24 November 2017.

Aditya Panji. Operator Seluler Dilarang.Umbar .Janji Palsu di Iklan (Ed: Reza Wahyudi) http://tekno.kompas.com. Diakses tanggal 24 November 2017.

Persatuan Perusahaan Periklanan Indonesia. http://www.p3ipusat.com diakses tanggal 24 November 2017.

Agung Kurniawan. "Adu Seksi Para Model Sepeda Motor". Dalam Kompas.com. diakses tanggal. 24 November 2017. 